\title{
Theodor Kocher (1841-1917) Nobel Prize Centenary 2009
}

\author{
Theodor Kocher (1841-1917) Centenário de Prêmio Nobel 2009
}

Peter Kopp ${ }^{1}$

1 Division of Endocrinology, Metabolism, and Molecular Medicine and Center for Genetic Medicine Feinberg School of Medicine Northwestern University Chicago, Illinois, USA

The author obtained his MD degree, and his training in Internal Medicine and Endocrinology at the University of Bern, Switzerland, the alma mater of Theodor Kocher who spent almost his entire medical career in Bern.

Correspondence to:

Peter Kopp

Division of Endocrinology, Metabolism and Molecula

Medicine Northwestern University Tarry 15

303 East Chicago Avenue

Chicago IL 60611

p-kopp@northwestern.edu

Received on Nov/29/2009

Accepted on Nov/30/2009

\begin{abstract}
One hundred years ago, in 1909, Theodor Kocher was awarded the Nobel Prize in Physiology and Medicine for his work on the physiology, pathology, and surgery of the thyroid gland. In the late $19^{\text {th }}$ century, the resection of the thyroid was feared because of its high mortality rate. Kocher's innovative techniques resulted in safe outcomes. His observations that radical resection of the thyroid results in "cachexia strumipriva" contributed to the recognition that the thyroid is essential for normal growth, development and metabolism. He made many other seminal contributions to the field of surgery and medicine, and his expertise was internationally recognized. Kocher served as the chairman of surgery at the University of Bern in Switzerland, his alma mater, until his death in 1917. Arq Bras Endocrinol Metab. 2009;53(9):1176-80
\end{abstract}

Keywords

Thyroid; iodine deficiency; goiter; history

\section{RESUMO}

Há 100 anos, em 1909, Theodor Kocher foi agraciado com o Prêmio Nobel de Fisiologia e Medicina pelo seu trabalho na fisiologia, na patologia e na cirurgia da glândula tireoide. No final do século XIX, a ressecção da tireoide era temida pelo alto índice de mortalidade. As técnicas inovadoras de Kocher resultaram como procedimento seguro. Suas observações de que a ressecção radical da tireoide resulta em cachexia strumipriva contribuiu no reconhecimento de que a tireoide é essencial no crescimento normal, no desenvolvimento e no metabolismo. Ele realizou muitas outras contribuições seminais no campo da cirurgia e da medicina, e seu conhecimento foi reconhecido internacionalmente. Kocher foi chefe da cirurgia da Universidade de Berna na Suíça, sua alma mater, até sua morte em 1917. Arq Bras Endocrinol Metab. 2009;53(9):1176-80

Descritores

Tireoide; deficiência de iodo; bócio; história
$\mathrm{T}$ heodor Kocher was born in 1841 in Bern, Switzerland (Figure 1) $(1,2)$. After completion of his high-school studies, he completed medical school at the University of Bern from 1860 to 1865 , and he was promoted to Doctor of Medicine in 1866. During medical school, he spent a short time at the University of Zürich, where he met the famous surgeon Theodor Billroth who greatly impressed him. After completing his medical studies, Kocher visited leading surgical clinics in Berlin, London and Paris (1865-1866) to deepen his surgical education. During his studies in England, he became aware of new antiseptic surgical techniques. Kocher was fluent in German, French and English, which allowed him to gain broad access to the important literature and to communicate with the thought leaders worldwide.

After his return to Bern, he became the assistant of the chairman of surgery (1866-1869), and he obtained his venia docendi, the license for academic teaching. Importantly, he introduced the new techniques of antiseptic wound treatment, which was still in its infancy. For financial reasons, he then entered private practice, but he continued to be actively engaged in academic teaching and research, and published his first important scientific contributions

In 1872, the former chair of surgery left Bern and, although the faculty proposed another candidate, the 
Board of Regents overruled their recommendation and appointed Kocher as chairman of the University Clinic of Surgery at the age of 31 years $(1,2)$. Kocher held this position for the next 45 years until his death in 1917, declining numerous offers from major European universities,

Under Kocher's tenure, the surgical clinic in Bern became an internationally known center that attracted numerous leading surgeons of his time, for example William Halsted, Harvey Cushing and Charles Mayo. Kocher developed a new style of surgery focusing on meticulous dissection of tissues, careful hemostasis, and strict adherence to antiseptic techniques. He carefully documented the clinical presentations, procedures and outcomes (3). Kocher also introduced statistical evaluation in order to analyze mortality rates, complications and outcomes. Moreover, he performed epidemiological studies, e.g. On the incidence of goiter in the canton of Bern (canton $=$ one of the 26 states of Switzerland). Kocher published more than 140 publications, among them the internationally acclaimed textbook of surgery, "Chirurgische Operationslehre", which was printed in five editions and translated into many languages.

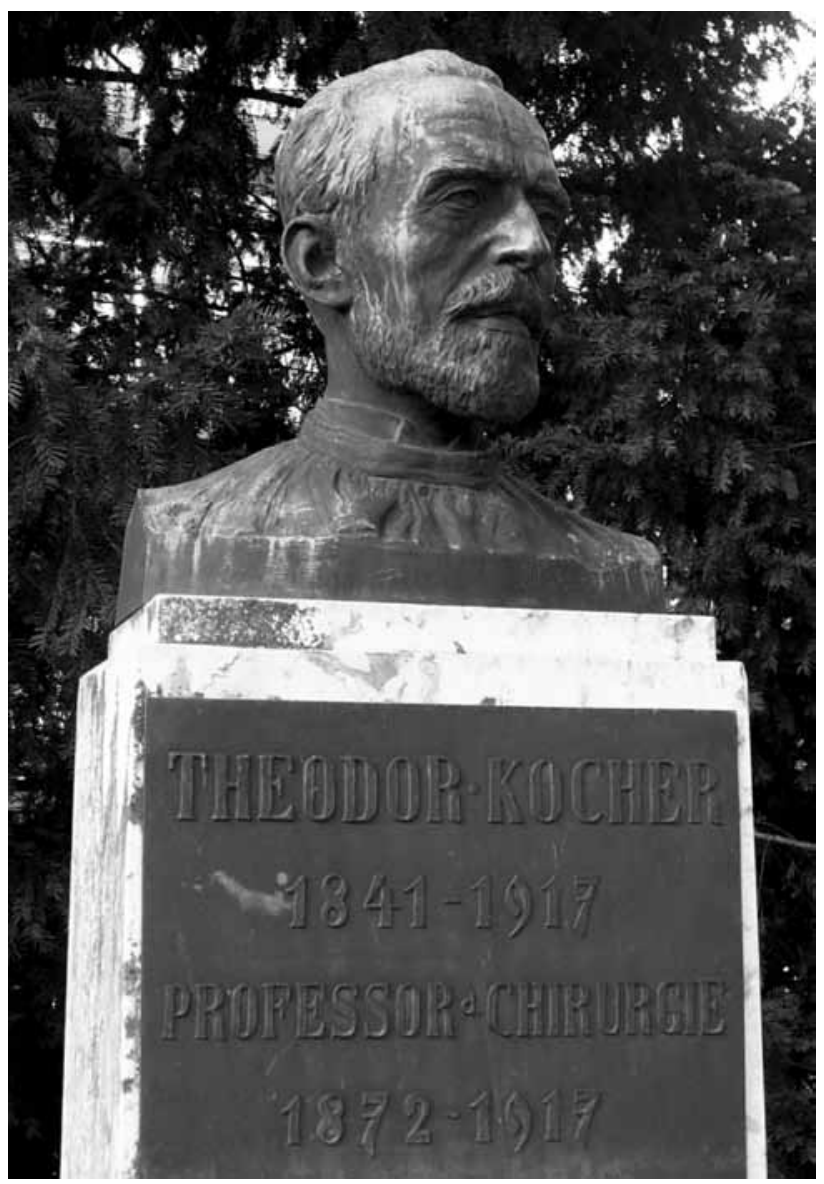

Figure 1. Sculpture of Theodor Kocher at the Inselspital, the University Hospital, in Bern, Switzerland, by Karl Hänny (photograph P. Kopp).
Kocher's most important area of research, including 23 publications, focused on the surgery and pathophysiology of the thyroid gland.

\section{CONTRIBUTIONS TO SURGERY AND PATHOPHYSIOLOGY OF THE THYROID}

Switzerland was a country with severe iodine deficiency and the population was heavily affected by endemic goiter and cretinism (4). The surgical resection of goiters was feared and associated with a very high mortality rate. Kocher improved the surgical techniques, and in his hands, mortality rates dropped significantly. Impressively, Kocher was involved in 7052 goiter resections, and 5314 of them were performed by him personally (2). In a first series of 101 thyroidectomies, presented in 1883 , he reported a mortality rate of $12.8 \%$. A series of 600 patients reported in 1898 included only 1 death and the mortality then remained below $1 \%$ in his hands. His technique was initially focused on a radical resection of the whole gland without injuring the recurrent nerve and the parathyroid glands whose function was unknown at that time. Similarly, the physiological function of the thyroid gland was not known in the late $19^{\text {th }}$ century.

In 1882, Jacques and Auguste Reverdin, two surgeons from Geneva, presented a condition resulting from total thyroidectomy and called it "myxoedème opératoi$r e$ ", profound hypothyroidism as a consequence of total thyroidectomy (5). Shortly thereafter (1883), Kocher presented similar outcomes in many of his patients at the Congress of the German Society for Surgery in Berlin and he coined the term "cachexia strumipriva" for the condition (6). Unfortunately, the three surgeons, who in all likelihood came independently to the conclusion that a radical resection of the thyroid gland is associated with a severe myxedematous phenotype, then had a longstanding feud over claims of priority.

A few years earlier, Gull (1873) had described the clinical entity of "myxoedema”, which was subsequently confirmed by Ord and associated with atrophy of the thyroid (1877). The Clinical Society of London established a committee to investigate the observations by Gull and Ord, as well as the findings of the Swiss surgeons, and it came to the insightful conclusion that myxedema, total thyroidectomy and cretinism all result from "the annibilation of the function of the thyroid body" (7).

Cachexia secondary to removal of a struma (struma = goiter). $m y x$ - excess content of mucin, oedema the swollen skin. 
In 1891, George Murray reported that injected sheep thyroid extract is able to cure myxedema (8). Shortly thereafter, Kocher reported in 1893 that the ingestion of raw thyroid tissue attenuated or cured the signs and symptoms in patients suffering from "cachexia strumipriva", findings that were confirmed by others (9). Based on these observations, Kocher abandoned his initial views that the thyroid was regulating the blood flow to the brain.

Total thyroidectomy was abandoned and replaced by partial thyroidectomies leaving the posterior part of the gland in place ("physiological surgery" rather than "radical surgery"). However, Kocher quickly realized that the so-called "subtotal" thyroidectomy resulted in goiter recurrences. This could only be avoided with the introduction of salt iodination (after 1920) and the availability of thyroxine (1930s). Total thyroidectomy through capsular dissection was only reintroduced in the 1980s.

\section{GOITER PROPHYLAXIS THROUGH ADMINISTRATION OF IODINE}

Coindet, a Swiss physician in Geneva, had described the reduction of goiter volumes by iodine already in 1820 , but this approach was abandoned because of its side effects, iodine-induced hyperthyroidism, or Jod-Base$d o w^{3}$. In 1825, Boussingault concluded that the lack of iodine was associated with the development of endemic goiter (10). In Switzerland, several physicians (Hunziker, Bayard, Eggenberger) demonstrated in the early 1900 that the administration of potassium iodide was able to impede the development of goiters. In 1913, the American thyroidologist David Marine (1880-1976) spent several weeks in Bern discussing thyroid problems with Kocher. Marine had shown that the addition of iodine to water reduced goiter formation in trout. $\mathrm{He}$, as Kocher, felt that goiter development was not the cause of iodine deficiency, but that the administration of iodine counteracted an unknown goitrogen. In 1917, shortly before his death, Kocher presented a talk at the Swiss Society for Surgery, where he still held this view. He mentioned the efficacy of prophylactic iodine administration to schoolchildren, but failed to discuss the beginning of goiter prophylaxis through iodination of table salt in Switzerland.

3 Jod = Iodine in German. Basedow $=$ Carl Adolph von Basedow (1799-1854), German physician who described the signs and symptoms of exophtalmic goiter independently of Graves and Parry. Morbus Basedow = Graves' disease.
Kocher concluded that iodine could be the active agent in the thyroid, but failed to demonstrate its presence, which was accomplished by Baumann in 1895 . The continuing search for the active principle produced by the thyroid gland ultimately led to the isolation of thyroxine by Kendall (1914), and its synthesis by Harrington in $1926(9)$.

\section{THE NOBEL PRIZE}

Kocher's numerous contributions to thyroid surgery and physiology, and his investigations into the causes of endemic goiter and cretinism, culminated in his receiving the Nobel Prize in Physiology and Medicine in 1909, the first surgeon to receive this honor (Figure 2). His Nobel lecture, entitled "Concerning pathological manifestations in low-grade thyroid diseases" is an impressive account of the efforts by himself and his contemporaries to improve surgical outcomes and obtain insights into the pathophysiology of the thyroid (11).

\section{KOCHER AND HARVEY CUSHING}

To the endocrinologists it is of interest to know that Kocher had a significant impact on Harvey Cushing (1869-1939). Cushing obtained his surgical training under the guidance of William Halsted at Johns Hopkins in Baltimore from 1896 to 1900 (12). Halsted visited Bern in 1899 and this encounter resulted in longlasting personal and professional interactions. Halsted supported Cushing's request for spending time with Kocher. Cushing spent 14 months in Europe between 1900 and 1901, 5 of them in Bern. Kocher proposed a research project addressing the factors responsible for regulating intracranial pressure to Cushing, who took on this challenge very successfully. In addition, he worked on muscle physiology under the guidance of Hugo Kronecker, a leading physiologist.

In this context, it is of interest to briefly sketch the history of transsphenoidal surgery for pituitary lesions. The transsphenoidal approach was developed in the early 1900s (13). Early attempts to choose this route were hampered by limited exposure, poor illumination, and disfiguring scars. In 1909, Kocher proposed an approach using submucosal dissection of the nasal septum for the resection of a pituitary adenoma in a patient with acromegaly (14). This was an important improvement because the submucosal resection reduced the risk of 


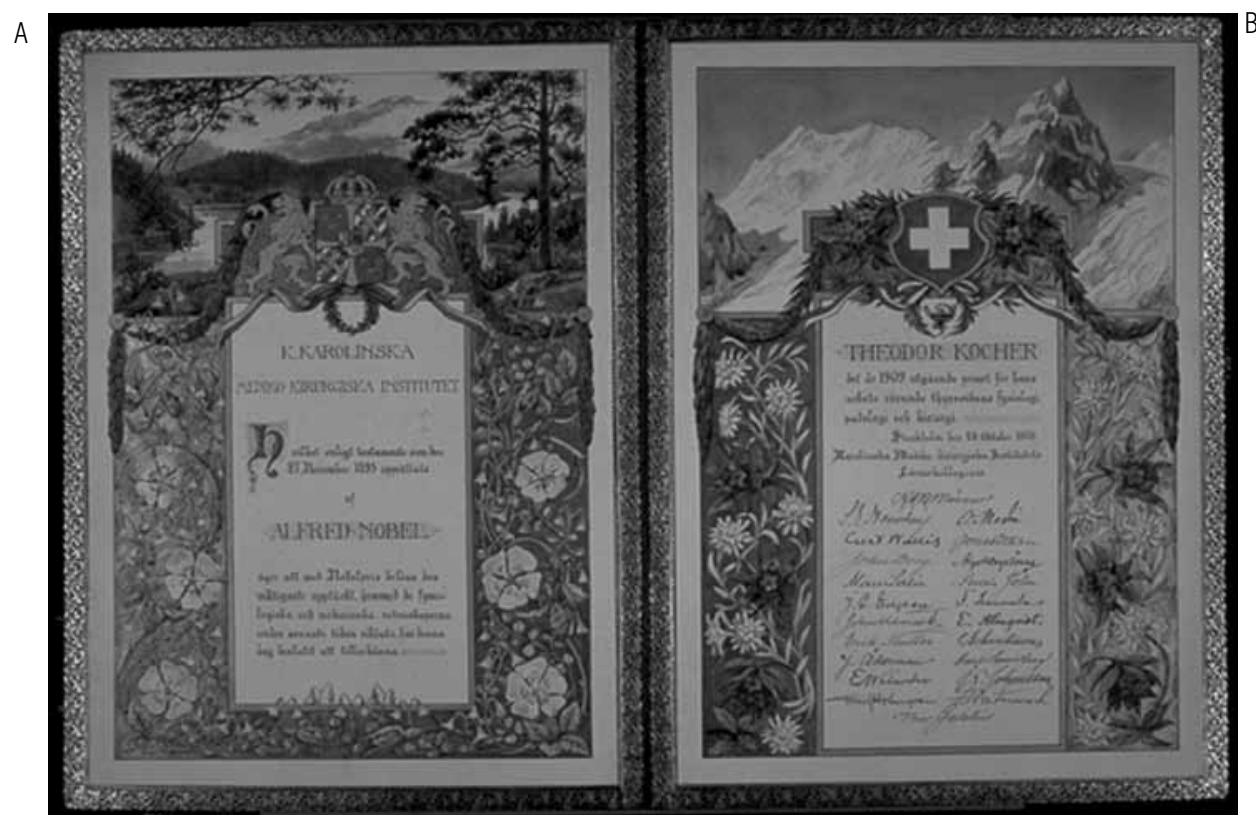

EMIL THEODOR KOCHER

\title{
Concerning pathological manifestations in low-grade thyroid diseases
}

\author{
Nobel Lecture*, December 11, 1909
}

Figure 2. A. Nobel Prize certificate issued to Theodor Kocher. B. Theodor Kocher's Nobel Prize presentation entitled "Concerning pathological manifestations in low-grade thyroid diseases" (http://nobelprize.org/nobel_prizes/medicine/laureates/1909/kocher-lecture.html).

infection and it led to a much better cosmetic result. Oskar Hirsch, a rhinologist from Vienna, further developed the endonasal approach (13). Cushing was aware of the work of these surgeons and he performed the first sublabial incision with submucosal resection of the septum in 1910, but he abandoned the transsphenoidal approach after 1929 in favor of the transcranial route (15). One of his mentees, Norman Dott from Edinburgh, continued to use and modify the transsphenoidal approach after his fellowship with Cushing. Gérard Guiot, a French neurosurgeon, learnt the transsphenoidal technique from Dott and, facilitated by improved illumination and intraoperative imaging, popularized it in the late $50 \mathrm{~s}$.

It is of interest to note that Kocher also contributed to the refinement of the transsphenoidal approach and it is clear that he had an important influence on the career choice and the way of thinking of Cushing, who glowingly acknowledged the mentorship and friendship of $\operatorname{Kocher}(1,2,13)$.

\section{OTHER PROFESSIONAL CONTRIBUTIONS AND HONORS}

In addition to his work on the thyroid, Kocher made significant contributions to many fields of surgery $(1,2)$. This included, among others, a new method to reduce dislocations of the shoulder, innovative approaches to hernia repair, gastrointestinal surgery (Kocher maneuver to mobilize the duodenum including the head of the pancreas), orthopedics, urology, shock, spinal cord and brain lesions, gun wounds, osteomyelitis, hemostasis and asepsis. The arterial clamp developed by Kocher in 1882 bears his name to this day.

Kocher trained numerous leading surgeons in Switzerland (e.g. César Roux, Fritz de Quervain, and his son Albert Kocher). He was well known in Europe and overseas through his widely translated scientific work and his intensive travels, both resulting in a lasting impact on surgeons and surgery worldwide. This is also reflected in his receiving of honorary memberships of numerous universities and professional societies. He was a foun- 


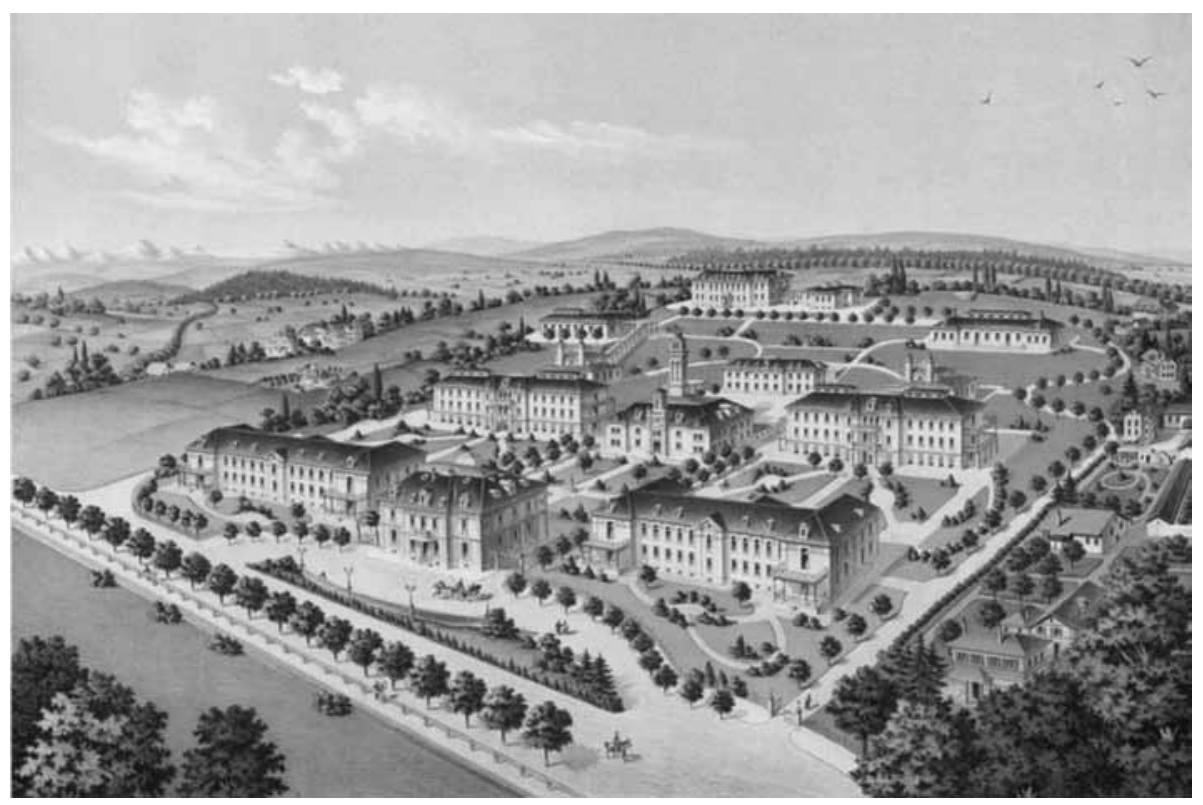

Figure 3. The University Hospital, the Inselspital, in Bern, Switzerland, in 1884.

ding member and the first president of the Swiss Society for Surgery, and he was the President of the German Society of Surgeons (1902) and the President of the First International Surgical Congress in Brussels in 1905.

\section{LEGACY}

Kocher, a humble man of strong religious convictions, was highly focused on his professional life, leaving almost no time to leisure $(1,2)$. He was loved by his patients, and cherished by his trainees and peers. His innovative concepts were instrumental for the construction of the new University Hospital, the Inselspital, in Bern (Figure 3). The Theodor Kocher Institute in Bern was built and financed with an endowment established with the Nobel Prize; the members of this institute continue to perform high-impact research in immunology, the blood-brain barrier, angiogenesis and platelet biology. For many years, members of the faculty in Bern continued to be actively engaged in thyroid research (e.g. Fritz de Quervain, Max Pierrre König, Hugo Studer, Hans Bürgi, Ueli Bürgi, Hans Gerber, Peter Kopp).

One hundred years after his receiving the Nobel Prize, there is no doubt that Kocher has an everlasting impact on modern surgery and medicine. Moreover, Kocher's exemplary professional dedication to his patients and medicine, his scientific rigor, and his humble humanism remain an inspiration to this date $(1,2)$.

Disclosure: no potential conflict of interest relevant to this article was reported.

\section{REFERENCES}

1. Bonjour E. Theodor Kocher. 2nd ed. Bern: Paul Haupt; 1981.

2. Tröhler U. Der Nobelpreisträger Theodor Kocher. Basel: Birkhäuser; 1984.

3. Isepponi O, Huwiler V, Boschung U. Theodor Kocher's surgical and clinical case presentations. Bull Hist Med. 2004;78:192-4.

4. Burgi H, Supersaxo Z, Selz B. lodine deficiency diseases in Switzerland one hundred years after Theodor Kocher's survey: a historical review with some new goitre prevalence data. Acta Endocrinol (Copenh). 1990;123:577-90.

5. Reverdin J. Accidents consécutifs à l'ablation totale du goitre. Rev Méd Suisse Romande. 1882;2:539.

6. KocherT. Ueber Kropfexstirpation und ihre Folgen. Arch Klin Chir. 1883;29:254-335.

7. Ord W. Report of a committee of the Clinical Society of London nominated December 14, 1883, to investigate the subject of myxoedema. Trans Clin Soc Lond. 1888;21(Suppl):1-215.

8. Murray G. Note on the treatment of myxoedema by hypothermic injections of an extract of the thyroid gland of a sheep. Br Med J. 1891;2:796-7.

9. Sawin C. The heritage of the thyroid. In: Braverman L, Utiger R, editors. Werner and Inbar's the Thyroid: a fundamental and clinical text. 7th ed. Phildadelphia: Lippincott-Raven Publishers; 1991. p. $2-5$.

10. Merke F. History and iconography of endemic goitre and cretinism. Bern: Hans Huber; 1984.

11. Kocher T. Concerning pathological manifestations in low-grade thyroid disease. The Nobel Prize website; 1909; Available from: http://nobelprize.org/nobel_prizes/medicine/laureates/1909/kocher-lecture.pdf.

12. Modlin IM. Surgical triumvirate of Theodor Kocher, Harvey Cushing, and William Halsted. World J Surg. 1998;22:103-13.

13. Lanzino G, Laws ER, Jr. Pioneers in the development of transsphenoidal surgery: Theodor Kocher, Oskar Hirsch, and Norman Dott. J Neurosurg. 2001;95:1097-103.

14. KocherT. Ein Fall von Hypophysis-Tumor mit operativer Heilung. Dtsch Z Chir. 1909;100:13-37.

15. Rosegay H. Cushing's legacy to transsphenoidal surgery. J Neurosurg. 1981;54:448-54. 